\title{
ANALISIS HUBUNGAN PENGETAHUAN DENGAN PERILAKU MASYARAKAT TERHADAP PENCEGAHAN PENULARAN COVID-19 DI KELURAHAN KORONG GADANG
}

\author{
Shanti Dafris \\ Akper Kesdam I/Bukit Barisan Padang \\ Email : shantidafris0688@gmail.com
}

\begin{abstract}
Abstrak
Coronavirus Disease 2019 atau Covid-19 merupakan pandemi yang telah menyebabkan tingginya angka mortalitas di berbagai belahan dunia termasuk Indonesia. Pentingnya kesadaran masyarakat untuk memutus rantai penularan Covid-19. Pengetahuan tentang Covid-19 sangat penting dimiliki oleh masyarakat sehingga masyarakat mampu untuk mengambil keputusan dalam berperilaku yang tepat dalam rangka memutus rantai penularan Covid-19. Tujuan penelitian yaitu untuk mengetahui analisis pengetahuan dan perilaku masyarakat terhadap pencegahan penularan Covid-19 di Kelurahan Korong Gadang. Penelitian ini merupakan penelitian kuantitatif. Sampel dalam penelitian ini adalah warga Kelurahan Korong Gadang berjumlah sebanyak 38 responden yang dipilih menggunakan teknik purposive sampling. Hasil penelitian menunjukan $65,8 \%$ responden memiliki pengetahuan yang tinggi tentang Covid-19, $68,4 \%$ responden memiliki perilaku yang baik terhadap pencegahan penularan Covid-19 dan terdapat hubungan pengetahuan dengan perilaku terhadap pencegahan penularan Covid-19.
\end{abstract}

Kata Kunci : Pengetahuan, Perilaku, Penularan Covid-19, Pencegahan Covid-19

\section{Abstract}

Coronavirus Disease 2019 or Covid-19 is a pandemic that caused high mortality rates in various parts of the world, including Indonesia. The importance of public awareness to break the chain of transmission of Covid-19. Knowledge about Covid-19 is fundamental, so people can make decisions about behaving appropriately to break the chain of transmission of Covid-19. The research objective was to determine the analysis of people's knowledge and behavior on preventing Covid-19 transmission in Kelurahan Korong Gadang. This research is quantitative. In this research, the sample was 38 residents of the Kelurahan Korong Gadang who were selected using the purposive sampling technique. The results showed that $65.8 \%$ of respondents had high knowledge about Covid-19, 68.4\% of respondents had good behavior towards preventing the transmission of Covid-19, and there was a relationship between knowledge and behavior towards the prevention of Covid-19 transmission.

Keywords: Knowledge, Behavior, Covid-19 Transmission, Covid-19 Preventition 


\section{PENDAHULUAN}

Corona Virus Disease 2019 atau Covid-19 adalah jenis penyakit baru yang disebabkan oleh infeksi Virus Severe Acute Respiratory Syndrome Coronavirus 2 (SARS-CoV-2) atau yang dikenal dengan Novel Coronavirus (2019-nCoV) (Singhal, 2020). Pandemi Covid-19 menjadi peristiwa yang mengancam kesehatan masyarakat secara umum dan telah menarik perhatian dunia. Pada Tanggal 30 Januari 2020, WHO (World Health Organization) telah menetapkan pandemi Covid-19 sebagai keadaan darurat kesehatan masyarakat yang menjadi perhatian dunia internasional (Guner, Hasanoglu, \& Aktas, 2020). Berdasarkan data Gugus Tugas Covid-19 Republik Indonesia, per tanggal 12 Agustus 2020, jumlah pasien total positif Covid-19 di dunia mencapai 20.388.408 orang, yang diakumulasikan dari pasien positif dirawat, pasien positif sembuh, serta pasien positif meninggal. Di Indonesia, total pasien positif Covid-19 sebesar 130.718 orang, dengan pasien sembuh sebesar 85.798 orang dan pasien meninggal sebesar 5.908 orang (Gugus Tugas COVID-19, 2020).

Peningkatan kasus Covid-19 yang terjadi di masyarakat didukung oleh proses penyebaran virus yang cepat. Penyakit ini ditularkan melalui droplet (percikan) pada saat berbicara, batuk dan bersin dari orang yang terinfeksi virus Corona. Selain itu penyakit ini juga dapat ditularkan melalui kontak fisik (sentuhan atau jabat tanggan) dengan penderita serta menyentuh wajah, mulut, hidung oleh tangan yang terpapar virus Corona (Singhal, 2020). Gejala klinis yang muncul akibat terinfeksi virus ini seperti gejala flu biasa (demam, batuk, pilek, nyeri tenggorokan, nyeri otot, nyeri kepala) hingga komplikasi berat (diare dan pneumonia) hingga menyebabkan kematian (Huang dkk, 2020). Hal ini akan meningkatkan ancaman dalam masa pandemik Covid-19 sehingga jumlah kasus Covid-19 di masyarakat dapat terus meningkat.

Guna melawan adanya peningkatan kasus Covid-19, maka berbagai tindakan preventif mutlak harus dilaksanakan, baik oleh pemerintah ataupun masyarakat. Upaya preventif sejauh ini merupakan praktik terbaik untuk mengurangi dampak pandemi Covid-19, mengingat belum adanya pengobatan yang dinilai efektif dalam melawan virus SARS-CoV-2. Saat ini, tidak adanya vaksin untuk SARS-CoV-2 yang tersedia dan telah memenuhi berbagai fase uji klinis, sehingga upaya preventif terbaik yang dilakukan adalah dengan memutus mata rantai penyebaran Covid-19 melalui isolasi, deteksi dini, dan melakukan proteksi dasar yaitu melindungi diri dan orang lain dengan cara sering cuci tangan dengan air mengalir dan sabun atau menggunakan sanitizer, menggunakan masker dan tidak menyentuh area muka sebelum mencuci tangan, serta menerapkan etika batuk dan bersin dengan baik (Dirjen P2P Kemkes RI, 2020).

Upaya pemutusan mata rantai penyebaran Covid19 memerlukan pemahaman dan pengetahuan yang baik dari seluruh elemen termasuk masyarakat. Pengetahuan masyarakat tentang Covid-19 sangat diperlukan sebagai dasar masyarakat dalam menunjukan perilaku pencegahan penularan Covid-19. Pengetahuan dan perilaku yang nyata dari masyarakat terkait tindakan pencegahan penularan Covid-19 akan senantiasi mampu menurunkan jumlah kasus Covid-19, sehingga masa pandemi Covid-19 dapat berakhir dengan cepat. Maka dari itu, peneliti tertarik untuk melakukan penelitian tentang analisis hubungan pengetahuan dengan perilaku masyarakat terhadap pencegahan penularan Covid-19 di Kelurahan Korong Gadang.

\section{METODE PENELITIAN}

Penelitian ini merupakan penelitian kuantitatif dengan desain deskriptif. Penelitian dilakukan pada bulan Desember tahun 2020. Sampel dalam penelitian ini adalah warga kelurahan Korong Gadang. Jumlah responden pada penelitian ini adalah sebanyak 38 responden yang dipilih menggunakan teknik purposive sampling. Kriteria inklusi penelitian ini antara lain : masyarakat yang tinggal di kelurahan Korong Gadang, bersedia menjadi responden dan bisa membaca.

\section{HASIL}

\section{A. Analisa Univariat} Kharakteristik Responden

Tabel 1.1 Distibusi Kharakteristik Responden

\begin{tabular}{lcc}
\hline \multicolumn{1}{c}{ Kharakteristik } & f & \% \\
\hline Usia & & \\
20-35 tahun & 11 & 28,9 \\
36-45 tahun & 15 & 39,5 \\
46-55 tahun & 9 & 23,7 \\
55-65 tahun & 3 & 7,9 \\
Jenis kelamin & & \\
Laki-laki & 15 & 39,5 \\
\hline & & Page | 2
\end{tabular}




\begin{tabular}{lcc}
\hline Perempuan & 23 & 60,5 \\
Pekerjaan & & \\
IRT & 5 & 13,2 \\
Karyawan Swasta & 22 & 57,9 \\
Wiraswasta & 8 & 21 \\
PNS & 3 & 7,9 \\
Tingkat & & \\
Pendidikan & 1 & 2,6 \\
SD & 4 & 10,5 \\
SMP & 13 & 34,2 \\
SMA & 20 & 52,6 \\
D3/S1 & & \\
\hline
\end{tabular}

Berdasarkan table 1.1 diatas, karakteristik responden berdasarkan usia yang paling banyak adalah usia 36-45 tahun 15 (39,5\%) responden, jenis kelamin yang paling banyak adalah jenis kelamin perempuan sebanyak $23 \quad(60,5 \%)$ responden, pekerjaan yang paling banyak adalah karyawan swasta $22(57,9 \%)$ responden dan tingkat pendidikan yang paling banyak adalah tingkat pendidikan D3/ S1 sebanyak $20(52,6 \%)$ responden.

\section{Tingkat Pengetahuan Responden Tentang Covid-19}

Tabel. 1.2

Tingkat Pengetahuan Responden Tentang Covid-19

\begin{tabular}{ccc}
\hline Pengetahuan & Frekuensi & $\%$ \\
\hline Tinggi & 25 & 65,8 \\
Sedang & 13 & 34,2 \\
Total & 38 & 100 \\
\hline
\end{tabular}

Berdasarkan table 1.2 diatas, pengetahuan responden tentang Covid-19 berada pada kategori tinggi sebanyak $25(65,8 \%)$ responden.

\section{Perilaku Responden Terkait Pencegahan Penularan Covid-19}

Tabel. 1.3

Distribusi Perilaku Responden Terkait Pencegahan Penularan Covid-19

\begin{tabular}{ccc}
\hline Perilaku & f & \% \\
\hline Baik & 26 & 68,4 \\
Cukup & 12 & 31,6 \\
Total & 38 & 100 \\
\hline
\end{tabular}

Berdasarkan table 1.3 diatas perilaku responden terkait pencegahan penularan
Covid-19 berada pada kategori baik sebanyak $26(68,64 \%)$ responden.

\section{B. Analisa Bivariat \\ Hubungan Pengetahuan dengan Perilaku Responden Terhadap Pencegahan Penularan Covid-19}

Tabel 1.4

Hubungan Pengetahuan dan Perilaku Responden Terhadap Pencegahan Penularan Covid-19

\begin{tabular}{c|c|c|c|c|c|c}
\hline \multirow{2}{*}{$\begin{array}{c}\text { Pengeta } \\
\text {-huan }\end{array}$} & \multicolumn{6}{|c}{ Perilaku } \\
\cline { 2 - 7 } & \multicolumn{2}{|c|}{ Baik } & \multicolumn{2}{c}{ Cukup } & \multicolumn{2}{c}{ Jumlah } \\
\cline { 2 - 7 } & $\mathrm{f}$ & $\%$ & $\mathrm{f}$ & $\%$ & $\mathrm{~F}$ & $\%$ \\
\hline Tinggi & 22 & 88 & 3 & 12 & 25 & $\begin{array}{c}10 \\
0\end{array}$ \\
\hline Sedang & 4 & 30,8 & 9 & 69,2 & 13 & $\begin{array}{c}10 \\
0\end{array}$ \\
\hline Total & 26 & & 12 & & 38 & $\begin{array}{c}10 \\
0\end{array}$ \\
\hline p-value 0,05 & & & & & &
\end{tabular}

Berdasarkan table 1.4 diatas di dapatkan hasil nilai $\mathrm{x}^{2}$ hitung $=12,99$ dengan nilai $\mathrm{x}^{2}$ tabel $=3,841$, dapat disimpulkan terdapat hubungan yang bermakna antara pengetahuan dengan perilaku masyarakat terhadap pencegahan penularan Covid-19.

\section{PEMBAHASAN}

Dari hasil penelitian didapatkan sebanyak 25 $(65,8 \%)$ responden pengetahuan berada pada kategori tinggi. Hasil penelitian ini sejalan dengan penelitian yang dilakukan oleh Yanti dkk (2020) dimana dari 1.102 respoden di Indonesia, mayoritas responden memiliki tingkat pengetahuan yang baik terkait social distancing dalam rangka pencegahan penularan Covid-19 dengan prevalensi mencapai 99\%. Selain itu penelitian lain yang dilakukan oleh Utami dkk (2020) juga memberikan hasil yang sejalan dengan penelitian ini yaitu $83 \%$ responden memiliki pengetahuan yang baik dalam pencegahan Covid19. Dari beberapa penelitian tersebut, maka dapat dilihat bahwa pengetahuan menjadi aspek penting yang perlu diperhatiakn dalam melakukan pemecahan terhadap permasalahan khususnya 
terkait Covid-19. Tingkat pengetahuan tinggi pada masyarakat di Kelurahan Korong Gadang didukung dengan tingkat pendidikan sebagian besar responden adalah pendidikan tinggi (diploma dan sarjana).

Salah satu faktor internal yang mempengaruhi tingkat pengetahuan seseorang adalah tingkat pendidikan, dimana semakin tinggi tingkat pendidikan seseorang maka semakin tinggi pula pengetahuan. Hal ini diperjelas oleh Mubarak dalam Muhammad Tauiq (2013) yang mengatakan bahwa semakin tinggi tingkat pendidikan seseorang semakin mudah mereka menerima informasi kesehatan. Sebaliknya jika seseorang yang tingkat pendidikannya rendah, maka akan menghambat perkembangan seseorang terhadap penerimaan, informasi kesehatan dan nilai-nilai baru yang diperkenalkan. Tingkat pendidikan seseorang yang tinggi akan semakin mudah untuk mendapatkan akses informasi tentang suatu permasalahan (Yanti B dkk, 2020). Pengetahuan masyarakat tentang Covid-19 merupakan aspek yang sangat penting dalam masa pandemic seperti sekarang ini, yang meliputi penyebab Covid-19 dan karakteristik virusnya, tanda dan gejala, istilah yang terkait dengan covid, pemeriksaan yang diperlukan dan proses transmisi serta upaya pencegahan penyakit tersebut. Pengetahuan masyarakat Korong Gadang yang tinggi tentang Covid-19 ini berpengaruh terhadap kejadian dan pencegahan penyakit Covid-19. Pengetahuan yang baik dapat didukung oleh penerimaan terhadap informasi yang beredar di masyarakat tentang covid-19 (Sulistyaningtyas, 2020). Menurut Olum R, Chekwueh dkk (2020) pendidikan professional berkelanjutan diperlukan untuk meningkatkan pengetahuan dan mengubah sikap negative serta meningkatkan praktik pencegahan dan pengobatan.

Perilaku yang baik dapat menjadi upaya pencegahan terhadap penularan Covid-19 (Audria, 2019). Eksplorasi tentang perilaku kesehatan masyarakat dapat dilihat dari berbagai komponen, diantaranya persepsi tentang kerentanan penyakit, persepsi hambatan dalam upaya pencegahan, persepsi tentang manfaat, adanya dorongan, dan persepsi individu tentang kemampuan yang dimiliki untuk melakukan upaya pencegahan (Almi, 2020). Dalam penelitian ini, menunjukkan sebanyak 26 $(68,4 \%)$ responden mempunyai perilaku baik dalam pencegahan penularan Covid-19. Bentuk perilaku yang ditunjukan antara lain kepatuhan dalam menggunakan masker saat berada diluar rumah, mencuci tangan dengan sabun atau sanitizer, menghindari kerumunan dan melakukan physical distancing. Cuci tangan adalah salah satu cara yang efektif untuk membunuh kuman, diketahui virus covid-19 dapat menempel pada bagian tubuh terutama tangan yang menyentuh benda yang sudah tertular oleh droplet.

Penelitian ini sejalan dengan penelitian yang dilakukukan oleh Purnamasari (2020) yang melakukan penelitian pada masyarakat Wonosobo dengan hasil masyarakat Wonosobo mempunyai perilaku yang baik pada pencegahan Covid-19. Hasil penelitian ini sejalan dengan penelitian lainnya, dimana dari 1.102 responden di Indonesia $93 \%$ memiliki perilaku yang baik terkait penerapan Social Distancing (Yanti B, dkk, 2020). Perilaku yang baik merupkan upaya untuk mencegah penularan Covid-19 (Purnamasari, 2020).

Perilaku yang baik dalam pencegahan penularan Covid-19 pada respoden salah satunya disebabkan oleh pengetahuan responden yang tinggi tentang Covid-19. Pengetahuan sangat penting dalam melanjutkan aspek sikap dan perilaku, karena jika seseorang tidak tahu maka tidak akan ada tindakan nyata yang dilakukan. Pengatahuan masyarakat dalam mencegah transmisi penyakit akan menekan penularan Covid-19 lebih lanjut (Law, Leung \& $\mathrm{Xu}, 2020)$.

Dari penelitian ini juga didapatkan hasil terdapat hubungan yang bermakna antara pengetahuan dan perilaku masyarakat terhadap pencegahan penularan Covid-19 dengan nilai $x^{2}$ hitung $\geq x^{2}$ tabel $\left(\mathrm{x}^{2}\right.$ hitung $=12,99$ dengan nilai $\mathrm{x}^{2}$ tabel $=$ 3,841). Hasil penelitian ini sejalan dengan penelitian yang dilakukan oleh Purnamasari (2020) dimana terdapat hubungan yang bermakna antara pengetahuan dengan perilaku masyarakat tentang Covid-19. Selain itu hasil penelitian ini juga sejalan dengan penelitian yang dilakukan oleh Prihati dkk (2020) dimana dari hasil penelitain menunjukan bahwa semakin baik pengetahuan masyarakat, maka semakin baik pula tindakan dalam pencegahan Covid-19.

Baiknya perilaku masyarakat di Korong Gadang dalam melakukan upaya pencegahan penularan Covid-19 dapat dipengaruhi oleh tingginya pengetahuan responden tentang Covid-19. Page $\mid 4$ 
Seseorang yang telah mengetahui tentang suatu informasi tertentu, maka dia akan mampu menentukan dan mengambil keputusan bagaimana dia harus menghadapinya. Dengan kata lain, saat seseorang mempunyai informasi tentang Covid-19, maka ia akan mampu untuk menentukan bagaimana dirinya harus berperilaku terhadap Covid-19 tersebut (Ahmadi, 2013). Perilaku seseorang menjadi aspek penting yang perlu diperhatikan dalam rangka mencegah dan menangani kasus Covid-19. Kepatuhan dalam melakukan pencegahan Covid-19 dipengaruhi oleh beberapa faktor antara lain pengetahuan, persepsi, motivasi dan keyakinan terhadap upaya pengontrolan dan pencegahan penyakit, terhadap lingkungan, pelayanan kesehatan, dan kemampuan mengakses sumber yang ada (Sinuraya, 2018).

Menurut teori Model Pengetahuan-SikapPerilaku, pengetahuan merupakan faktor esensial yang dapat mempengaruhi perubahan perilaku, dan individu dapat memperoleh pengetahuan dan keterampilan melalui proses belajar (Liu et al, 2016). Dengan demikian pengetahuan masyarakat yang masih perlu diluruskan dan perilaku masyarakat yang masih negatif dapat diupayakan dengan kegiatan pembelajaran melalui edukasi oleh pihak-pihak berwenang. Masyarakat tidak patuh terhadap protokol kesehatan pandemi Covid-19 disebabkan masyarakat kurang memiliki pemahaman resiko tertular Covid-19, tujuan pencegahan dan bagaimana prosedur pemakaian APD. Dengan masyarakat memiliki pemahaman dan persepsi yang baik, maka resiko tertular Covid-19 bisa dicegah.

Upaya pemutusan mata rantai penyebaran Covid19 tidak akan berjalan sebelum masyarakat dibekali dengan pengetahuan dan perilaku yang baik dalam upaya pencegahan penularan COVID-19. Pengetahuan dan perilaku yang nyata dari masyarakat terkait tindakan pencegahan penularan Covid-19 akan senantiasi mampu menurunkan jumlah kasus COVID-19, sehingga masa pandemi COVID-19 dapat berakhir dengan cepat.

\section{KESIMPULAN}

1. Hasil penelitian ini menunjukan bahwa $65,8 \%$ responden memiliki pengetahuan yang tinggi tentang pencegahan penularan Covid19.
2. Hasil penelitian menunjukan bahwa $68,4 \%$ responden memiliki sikap yang baik terkait dengan pencegahan penularan Covid-19

3. Hasil penelitian menunjukan terdapat hubungan yang bermakna antara pengetahuan dan perilaku responden terhadap pencegahan penularan Covid-19.

\section{Saran}

Perlu adanya kesadaran dari masyarakat untuk mentaati protokol kesehatan dimasa pandemi Covid-19 dengan perubahan perilaku yaitu menggunakan masker, physical distancing serta perilaku hidup bersih dan sehat, dan diharapkan pada peneliti selanjutnya agar dapat melakukan penelitian ini dengan variabel yang lebih banyak dan jumlah responden yang lebih luas.

\section{DAFTAR PUSTAKA}

Ahmadi. (2013).Kesehatan Masyarakat, teori dan aplikasi. Jakarta: Raja Grafindo.

Almi. (2020). Analisis Penyebab Masyarakat Tidak Patuh Pada Protokol Covid-19.

Retrieved from

https://almi.or.id/2020/06/05/analisispenyebab-masyarakat-tidak-patuh- padaprotokol-covid-19/diakses 28 Juni 2020

Audri Okta AWD. (2019). Hubungan Pengetahuan dan Sikap Terhadap Perilaku Cuci Tangan pada Masyarakat Kelurahan Pegirian, Jurnal Promkes : The Indonesian Journal of Health Promotion And Health Education, vol 7 No, 1 (2019) 1-11 DOI : 10.20473/jpk.V7.11.2019 .1-11. Retrieved from https://e-

journal.unair.ac.id/PROMKES/article/vie $\underline{\mathrm{w} / 7122}$

Direktorat Jenderal Pencegahan dan Pengendalian Penyakit Kemetrian Kesehatan RI (2020). Pedoman Kesiapsiagaan Menghadapi Corona Virus Disease (COVID-19), Jakarta. Retrieved from

https://infeksiemerging.kemkes.go.id/dow nload/SURAT_EDARAN_DIRJEN_P2P 270_2020_Pedoman_Kesiapsiagaan_Men ghadapi_Infeksi_Novel_Coronavirus.pdf

Gugus Tugas COVID-19. (2020). Peta Sebaran Data COVID-19. Retrieved from https://covid19.go.id/peta-sebaran 
Güner, R., Hasanoğlu, İ., \& Aktaş, F. (2020). Covid-19: Prevention and control measures in community. Turkish Journal of Medical Sciences, 50(SI-1), Retrieved from

https://pubmed.ncbi.nlm.nih.gov/322938 $\underline{35 /}$

Huang C, Wang Y, Li X. (2020). Clinical features of patients infected with 2019 novel coronavirus in Wuhan, China. Lancet. 395: 497-506

Law, S., Leung, A. W., \& Xu, C. (2020). Severe acute respiratory syndrome (SARS) and coronavirus disease-2019 (COVID19): From causes to preventions in Hong Kong. International Journal of Infectious Diseases, 94, 156-163.

$\begin{array}{llll}\text { Liu, L. } & \text { et } & \text { al. } & \text { (2016) } \\ & \text { 'Use } & \text { of } & \text { a }\end{array}$ knowledgeattitude-behaviour education programme for

Chinese adults undergoing maintenance haemodialysis: Randomized controlled trial', The Journal of internationalmedical research.

2016/03/07. SAGE Publications, 44(3), pp. $\quad 557-568$. doi: $10.1177 / 0300060515604980$.

Muhammad Tauiq, M. N. \& S. R. (2013). Gambaran Prilaku Hidup Bersih dan Sehat (PHBS) Masyarakat Di Kelurahan Parangloe Kecamatan Tamalanrea Kota Makassar. 1-12. Retrieved from repository.unhas.ac.id

Olum R, Chekwech G et al (2020).

Coronavirus Disease-2019: Knowledge, Attitude, and Practices of Health Care Workers at Makerere University Teaching Hospitals Uganda, Original Research

Prihatin dkk (2020). Analisis pengetahuan dan perilaku masyarakat di kelurahan baru kotowaringin barat tentang Covid-19. Manuju Malayati Nursing Journal, PISSN : 2655-2728 E-ISSN : 2655-4712 Volume 2, Nomor 4 September 2020 Halman 780-790. Retrieved from http://ejurnalmalahayati.ac.id/index.php/ manuju/article/view/3073
Purnamasari. (2020). Tingkat Pengetahuan Dan Perilaku Masyarakat Kabupaten

Wonosobo Tentang Covid-19. Jurnal Ilmiah Kesehatan, (Mei), 33-42. Retrieved from https://ojs.unsiq.ac.id/index.p $\mathrm{hp} / \mathrm{jik} /$ article/view/1311/783

Singhal, T. (2020). A Review of Coronavirus Disease-2019 (COVID-19). The Indian Journal of Pediatrics, 87(4): 281-286.

Sinuraya, R. (2018). Medication Adherence among Hypertensive Patients in Primary Healthcare in Bandung City. Indonesian Journal of Clinical Pharmacy, 7(2), 124$133 . \quad$ Retrieved from https://doi.org/10.15416/ijcp. 2018.7.2.124

Sulistyaningtyas Tri (2020), Informasi Wabah Virus Covid-19: Kuasa Pengetahuan dan Kelas Sosial. Retrieved from https://sinta.ristekbrin.go.id/covid/pen elitian/detail/80,

SIHOMBING, Ida Mariana. PENGETAHUAN IBU RUMAH TANGGA TERHADAP GARAM BERYODIUM. Jurnal Ilmiah Cerebral Medika, 2020, 2.1: 2-2.

Utami, R. A., Mose, R. E., \& Martini, M. (2020). Pengetahuan, Sikap dan Keterampilan Masyarakat. Retrieved from https://ejournal.stikesrshusada.ac.id/index.p $\mathrm{hp} / \mathrm{jkh} /$ article/view/85

Yanti, B., Wahyudi, E., Wahiduddin, W., Novika, R. G. H., Arina, Y.M. D., Martani, N. S., \& Nawan, N. (2020). Community Knowledge, Attitudes, and Behavior Towards Social Distancing Policy As Prevention Transmission of Covid-19 in Indonesia. Jurnal Administrasi Kesehatan Indonesia, 8(2), 4. Retrieved from https://doi.org/10.20473/jaki.v8i 2.2020.4$\underline{14}$ 
Jurnal Ilmiah Cerebral Medika, Vol.2.No 2 (2020)

Vol.2.No 2 (2020)

p-ISSN :2657-2435

e-ISSSN:2721-3145 